\title{
Nitrate Contamination in Brazilian Urban Aquifers: A Tenacious Problem
}

\author{
Ricardo Hirata ${ }^{1, *(\mathbb{D}}$, Fabiana Cagnon ${ }^{1}\left(\mathbb{D}\right.$, Aline Bernice ${ }^{1}\left(\mathbb{D}\right.$, Carlos Henrique Maldaner ${ }^{1,2} \mathbb{D}^{\mathbb{D}}$, \\ Paulo Galvão ${ }^{3}{ }^{(D)}$, Carlos Marques ${ }^{1}(\mathbb{D})$, Rafael Terada ${ }^{1}\left(\mathbb{D}\right.$, Claudia Varnier $^{1,4} \mathbf{D}^{\mathbb{D}}$, \\ M. Cathryn Ryan ${ }^{5}$ (D) and Reginaldo Bertolo ${ }^{1}$ (D) \\ 1 CEPAS|USP Groundwater Research Center, Institute of Geosciences, University of São Paulo, \\ São Paulo 05508-080, Brazil; fa.cagnon@uol.com.br (F.C.); alinebernice@hotmail.com (A.B.); \\ carlos.henrique.marques@usp.br (C.H.M.); cmaldane@uoguelph.ca (C.M.); rafael.terada@usp.br (R.T.); \\ claudia.varnier@sp.gov.br (C.V.); bertolo@usp.br (R.B.) \\ 2 G360 Institute for Groundwater Research, University of Guelph, Guelph, ON N1G 2W1, Canada \\ 3 Pampulha Campus, Department of Geology, Federal University of Minas Gerais, Belo Horizonte 31270-901, \\ Brazil; hidropaulo@gmail.com \\ 4 Geological Institute, Secretariat of Infrastructure and Environment of the Government of the State of São \\ Paulo, São Paulo 04015-12, Brazil \\ 5 Geosciences Department, University of Calgary, Calgary, AB T2N 1N4, Canada; cryan@ucalgary.ca \\ * Correspondence: rhirata@usp.br; Tel.: +55-11-3091-4243 or +55-11-99482-0864
}

Received: 31 August 2020; Accepted: 24 September 2020; Published: 27 September 2020

\begin{abstract}
This study follows the geochemistry of nitrogen in a Cretaceous and unconfined sedimentary aquifer in the city of Urânia (Brazil) over 20 years. Although the sewer network was built in the 1970s, the nitrate contamination problem $\left(>45 \mathrm{mg} / \mathrm{L}_{-} \mathrm{NO}_{3}{ }^{-}\right)$persists to this day. The oldest urbanization areas located in the north of the city initially used cesspits for wastewater and currently present the highest nitrate concentrations ( $>120 \mathrm{mg} / \mathrm{L}_{-} \mathrm{NO}_{3}{ }^{-}$), with the plume reaching the deeper aquifer portions (up to $100 \mathrm{~m}$ ). The contamination is not as dramatic in the south part of the city, where urbanization including installation of the sewage network with PVC pipes that are more resistant to leak than the old ceramic networks occurred after 1985. Based on the constructive well profiles, three hydrogeochemical zones were established: shallow ( $<20 \mathrm{~m}$ deep), with average nitrate of $63 \mathrm{mg} / \mathrm{L}_{-} \mathrm{NO}_{3}{ }^{-}$; intermediate

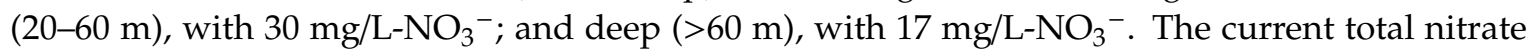
mass in the aquifer exceeds $731 \mathrm{~kg}-\mathrm{NO}_{3}{ }^{-}$. Numerical flow (Modflow) and transport (MT3D) model scenarios support the hypothesis that the nitrate contamination is caused by substantial infiltration of nitrogen through the cesspits until the 1970s, but after the 1990s, leaks from the sewer network should be responsible for the maintenance of the recently observed high concentrations of nitrate.
\end{abstract}

Keywords: nitrate; groundwater contamination; urban hydrogeology; urban aquifer recharge

\section{Introduction}

Nitrate is one of the most ubiquitous pollutants in groundwater in the world. At concentrations higher than $45 \mathrm{mg} / \mathrm{L} \mathrm{NO}_{3}{ }^{-}\left(10 \mathrm{mg} / \mathrm{L} \mathrm{N}-\mathrm{NO}_{3}{ }^{-}\right)$, it causes methemoglobinemia and cancer [1,2]. The origins of this contamination have been widely studied and are associated with the use of inorganic fertilizers in agriculture [3-5] and in intensive animal husbandry [6], in addition to inefficient sanitation systems (septic tanks or cesspits) [7,8] and leakage from public sewer mains [9-11].

The presence of nitrate in groundwater in cities is related to the management of its effluents; however, its distribution in the aquifer is also associated with urban infrastructure, which changes recharge patterns. Cities alter the circulation of water completely; thus, it is essential to relate sewage leaks to the urban occupation and the various sources of water that enter the aquifer. In Liverpool, 
England, losses in the water supply network resulted in leaks of $36.5 \mathrm{Mm}^{3} / \mathrm{y}$, with a refill equivalent to $180 \mathrm{~mm} / \mathrm{y}$ [12]. In Hat Yai, Thailand, there was an increase of $97 \mathrm{~mm} / \mathrm{y}$ for an urban refill of $240 \mathrm{~mm} / \mathrm{y}$ (40.4\%) [13]. In Toluca, Mexico, $27 \%$ of public water is lost, which is equivalent to $10.6 \mathrm{Mm}^{3} / \mathrm{y}$ [14]. Regarding leaks from sewage networks, there are far fewer studies. In Nottingham and Doncaster, in the UK, the values were $0.33 \mathrm{Mm}^{3} / y$ and $0.13 \mathrm{Mm}^{3} / \mathrm{y}$, respectively $\left.[15,16]\right)$. In central London, the UK, it is estimated that there are losses of $0.9 \mathrm{Mm}^{3} / \mathrm{y}$.

In developing countries, where there is less maintenance of sewage networks, leakage is expected to be higher, reaching $5-15 \%$ of the total effluent circulating in the mains $[17,18]$. The contamination observed in Brazilian cities such as Natal (Rio Grande do Norte), Belém (Pará) and Sete Lagoas (Minas Gerais) [17-21] show that these values are realistic. The old sewage network, lacking maintenance and built with ceramic pipes, was quite common until the end of the 1990s; it is one of the causes of contamination of cities in the State of São Paulo [18], as is the case in the urban areas of São José do Rio Preto [22], Bauru [23,24], Marília [24], Presidente Prudente [25] and Urânia [11].

Nitrate contamination in an unconfined sedimentary aquifer has been studied in Urânia (Figure 1) since the 1990s. The city has a population of around 9000 people, a typical residential occupation, a common pattern to small urban centers in the interior of São Paulo. Dug wells and shallow tubular wells (up to $60 \mathrm{~m}$ ) have shown high nitrate concentrations in plumes that extend over almost all of its urban area, although the sewage network has been installed since the 1970s and today reaches more than $98 \%$ of the population.

This article aims to establish the extent and evolution of the nitrate problem that has affected the Adamantina Aquifer under the city of Urânia since the founding in 1950. The work also quantifies the nitrate mass in the aquifer, using temporal and spatial analysis of land use and occupation. To accomplish this, potential sources of contamination were mapped during visits to almost all residences in the city. This study's originality is in monitoring the nitrate contamination evolution and the geochemical and isotopic groundwater for more than 20 years, which allowed us to evaluate the contaminating plume's future development using a numerical model of flow and transport.

\section{Site Description}

The municipality of Urânia is in the northwest region of the State of São Paulo, with an area of $210 \mathrm{~km}^{2}$ and a population of 9135 inhabitants [26]. The urban center occupies $2.14 \mathrm{~km}^{2}$, where $80 \%$ of the population lives (Figure 1). Since its founding in 1953 until the present, its main economic activity is agriculture. Between the 1950s and 1990s, cotton grew, followed by coffee and, to a lesser extent, corn, rice, and peanuts. The cultivation of oranges and grapes began in the 1980s and 1990s, respectively, when the use of inorganic nitrogen fertilizers was introduced systematically.

Urânia has a humid tropical climate [27], with two well-defined seasons: hot summers, with monthly averages above $25^{\circ} \mathrm{C}$ (September-April); and cold winters, with monthly averages below $22^{\circ} \mathrm{C}$ (May-August). Between 1988 and 2018, the Urânia rain station (B7-006) recorded average annual rainfall of $1317 \mathrm{~mm}$. The months December to March are predominantly humid, with an average rainfall of $206 \mathrm{~mm} / \mathrm{month}$, while the months June to August are relatively drier, with an average rainfall of $21 \mathrm{~mm} / \mathrm{month}$.

Geomorphologically, the region is in the Planalto Centro-Ocidental Paulista, characterized by slightly rolling, wide and low hills, with convex and flattened tops and average topographic levels of 458 masl. The drainage is not very dense and has, in general, a parallel pattern, mostly organized by consequent rivers. The main streams are the Comprido and the Matadouro (Figure 1), both belonging to the Turvo river basin. 

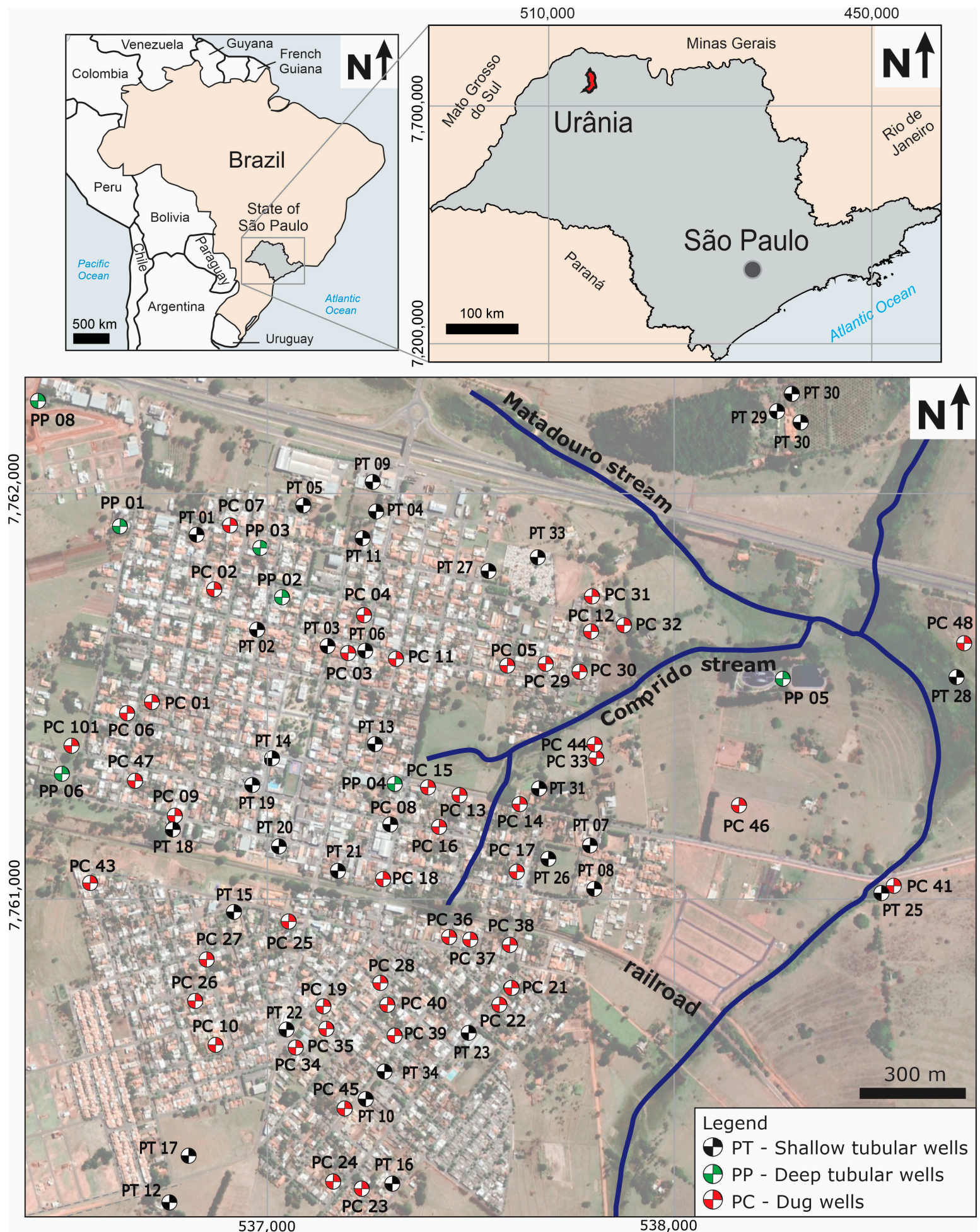

Figure 1. The city of Urânia (São Paulo, Brazil) and its dug wells $(<20 \mathrm{~m})$, shallow tubular wells (20 m-60 m) and deep tubular wells (>60 m).

Geologically, the region is inserted in the volcanic-sedimentary Basin of Paraná, filled with continental and marine sediments and basaltic lava from the Serra Geral Formation. In Urânia, Cretaceous sedimentary rocks of the Adamantina Formation (Bauru Group) outcrop and are deposited on the Serra Geral Formation. The Adamantina Formation, the unit with the most extensive surface distribution in the State of São Paulo, is composed of fine silty to very clayey sandstones, with a 
reddish-brown color. The grains are sub-rounded and well-selected, distributed in layers with a thicknesses of from 66 to $165 \mathrm{~m}$. The Serra Geral Formation is a set of spills of acidic and basic basaltic lavas characterized by aphanitic dark gray to black rocks, and in Urânia, they are melanocratic and thin phaneritic, and have a thicknesses greater than $1000 \mathrm{~m}[28,29]$.

Two hydro-stratigraphic units occur in Urânia, the Adamantina Aquifer, which is the focus of the study. It is of the unconfined to semi-confined type, is slightly heterogeneous and isotropic, and is limited in its lower portion by the basalts. The Serra Geral Aquifer when outcropped is fractured, unconfined, anisotropic and heterogeneous. The average hydrodynamic parameters for the Adamantina Aquifer in regional values for hydraulic conductivity $(\mathrm{K})$ are between $10^{-6}$ and $10^{-5}$ $\mathrm{m} / \mathrm{s}$. Its recharge occurs naturally through the rain infiltration [30]. The average annual rainfall varied from 1000 to $1500 \mathrm{~mm}$, with potential monthly evapotranspiration between 50 and $146 \mathrm{~mm}$ and an average recharge of $272 \mathrm{~mm}$ (2007-2009), resulting in variations in the average water table of $2.6 \mathrm{~m}$ over the year.

\section{Materials and Methods}

The same group of researchers has studied Urânia since the 1990s, allowing monitoring of the territorial evolution and its urban infrastructure, as well as the geochemical changes of groundwater. Many of the benefits from this long period, including evaluations of hydrogeochemical data, have not been published.

\subsection{Hydrogeological Conceptual Model of the Adamantina Aquifer}

The conceptual model involved the survey and interpretation of data available over the years of study in Urânia. The altimetry data were obtained from the topographic sheets of Santa Albertina and Jales, scale 1:50,000 [31,32]. Geological and hydrogeological information was compiled from several authors [7,11,33-37], as well as lithoconstructive profiles of tubular wells [38,39] and geophysical vertical electrical soundings carried out by Pálmer-Rivera (2002) [37].

The tubular and dug wells in the city were divided into three groups according to the drilling depth and the filter position. Dug wells generally draw shallower water, with surface depths of up to $20 \mathrm{~m}$ (shallow zone, SZ). Among the tubular wells, there are shallow wells, with depths up to $60 \mathrm{~m}$ (intermediate zone, IZ), and deep wells, with depths from 60 to $120 \mathrm{~m}$ (deep zone, DZ).

Cagnon (2003) acquired hydraulic parameters of the Adamantina Aquifer by pumping test [7]. Measurements of depth, thickness, and hydraulic level of surface water bodies were obtained by Pálmer-Rivera (2002) [37] and Cagnon (2003) [7]. For the estimation of recharge and evapotranspiration in rural areas, we considered the premises of Bertolo et al. (2006) [34], who monitored the zone using pressure tensiometers, while for the urban area, we used data from Maldaner (2010) [30], who made estimations using water balance and water level fluctuation techniques.

\subsection{Evolution of Urban Occupation and Assessment of Potential Contamination}

First, we performed registration and mapping of dug and tubular wells, as well as septic tanks and cesspits (classified as active or inactive), using visits almost a thousand homes, interviewing owners and consulting the Municipal Secretariat's Saúde de Urânia database and SABESP (The Basic Sanitation Company of the State of São Paulo). Agricultural activities present in urban properties were also identified, including small gardens, using manure and inorganic nitrogen fertilizers. To analyze the history of land use and occupation as well as the evolution of the installation of public water supply and sewage networks, aerial photographs at various dates were used (1962, scale 1:27,000; 1965, 1:60,000; 1971, 1:25,000; 1985, 1:25,000), as well as Landsat-5 satellite images (scene 222/074 of 22 June 1997, with 3, 4, and 5 band-composition), Google Earth (scenes from 2000 to 2019), field verification, and interviews with employees of the city hall and SABESP. The data were organized in a geographic information system (ArcGis 10.2). The coordinate system was Universal Transverse Mercator (UTM) projection, zone 23, South American Datum (SAD) 69, with units in meters. 


\subsection{Sampling, Chemical, Physicochemical, and Stable Isotope Analysis}

The water collections were made in three phases: (1) June 1998 to September 2001 (nine campaigns); (2) September 2007 to September 2009 (three campaigns); and (3) July 2018 and September 2019 (two campaigns). In total, 463 samples were collected in 49 dug wells, 40 tubular wells, and 4 multilevel monitoring wells over almost 20 years (Table 1 ).

Table 1. Groundwater samples for chemical and isotopic analysis.

\begin{tabular}{|c|c|c|c|c|c|}
\hline Sampling & Dug Well & $\begin{array}{l}\text { Tubular } \\
\text { Well }\end{array}$ & $\begin{array}{l}\text { Monitoring } \\
\text { Well }\end{array}$ & $\begin{array}{l}\text { Chemical } \\
\text { Analyzes }\end{array}$ & $\begin{array}{c}\text { Stable } \\
\text { Isotopes }\left({ }^{18} \mathrm{O},\right. \\
\left.{ }^{2} \mathrm{H},{ }^{15} \mathrm{~N}\right)\end{array}$ \\
\hline January 98 (lab) & 14 & 10 & - & 24 & - \\
\hline November 98 (lab) & 9 & 5 & - & 14 & - \\
\hline March 99 (lab) & 11 & 10 & - & 21 & - \\
\hline January 99 (lab) & 13 & 8 & - & 21 & - \\
\hline April 00 (lab) & 11 & 9 & - & 20 & - \\
\hline April 00 (field) & 31 & 19 & & 50 & \\
\hline August 00 (lab) & 9 & 4 & - & 13 & - \\
\hline August 00 (field) & 24 & 20 & & 44 & \\
\hline February 01 (lab) & 8 & 5 & - & 13 & - \\
\hline February 01 (field) & 25 & 19 & & 44 & \\
\hline August 01 (lab) & 10 & 5 & - & 15 & - \\
\hline August 01 (field) & 25 & 18 & & 43 & \\
\hline September 01(lab) & 11 & 6 & - & 17 & $17\left({ }^{15} \mathrm{~N}\right)$ \\
\hline September 01(field) & 12 & 7 & & 19 & \\
\hline September 07 (lab) & 15 & 13 & 5 & 33 & $26\left({ }^{18} \mathrm{O},{ }^{2} \mathrm{H}\right)$ \\
\hline September 08 (lab) & 8 & 12 & 5 & 25 & $39\left({ }^{18} \mathrm{O},{ }^{2} \mathrm{H}\right)$ \\
\hline March 09 (lab) & 8 & 10 & - & 18 & $25\left({ }^{18} \mathrm{O},{ }^{2} \mathrm{H}\right)$ \\
\hline January 18 (lab) & 5 & 15 & 2 & 22 & \\
\hline \multirow[t]{2}{*}{ September 19 (lab) } & & & 7 & 7 & \\
\hline & & & Total & 463 & \\
\hline
\end{tabular}

(field): using portable colorimetric equipment; (lab): traditional laboratory facility.

For a temporal assessment of chemical variations, 43 dug and tubular wells were selected, sampled during four campaigns, distributed over four seasons of a hydrogeological year. In the September 2001 campaign, water samples were collected for stable isotopes analysis $\left(\delta^{18} \mathrm{O}\right.$ and $\left.\delta^{2} \mathrm{H}\right)[40]$, dissolved organic carbon (DOC), and nitrate isotope $\left(\delta^{15} \mathrm{~N}\right)$. Wells were selected based on nitrate concentrations and location concerning the history of use and land occupation. Water sampling was made directly at the wellhead using the well's pumping equipment. Care was taken to pump at least one volume of the well in the tubular wells, and pumping in the dug wells was carried out for $30 \mathrm{~min}$. In the case of multilevel monitoring wells, the sampling method was low-flow using the pneumatic groundwater-sampling pump [41].

The physicalchemical parameters measured in the field were as follows: $\mathrm{pH}$, Eh, electrical conductivity (EC), temperature, and dissolved oxygen (DO) using a multi-parameter probe (YSI-Professional) and alkalinity by titration with standard $\mathrm{H}_{2} \mathrm{SO}_{4}$. The chemical parameters $\mathrm{NO}_{3}{ }^{-}$, $\mathrm{NO}_{2}{ }^{-}, \mathrm{NH}_{4}{ }^{+}, \mathrm{Cl}^{-}$, and $\mathrm{Fe}^{2+}$ were analyzed using colorimetric methods in the field (Merck RQFlex), 
of which $30 \%$ of the samples were also analyzed by ion chromatography, flame spectrometry, and atomic absorption, including major and minor ions $\left(\mathrm{Ca}^{2+}, \mathrm{Mg}^{2+}, \mathrm{K}^{+}, \mathrm{Na}^{+}, \mathrm{SO}_{4}{ }^{3-}, \mathrm{F}^{-}, \mathrm{PO}_{4}{ }^{3-}, \mathrm{Br}^{-}, \mathrm{Cl}^{-}, \mathrm{Zn}^{2+}\right.$, $\mathrm{Sr}^{2+}, \mathrm{Ba}^{2+}, \mathrm{Fe}_{\text {total }}, \mathrm{Mn}^{2+}, \mathrm{Al}^{3+}, \mathrm{Cr}_{\text {total }}, \mathrm{Pb}^{2+}, \mathrm{Cu}^{2+}, \mathrm{Ni}^{+}$, and $\left.\mathrm{Ag}^{+}\right)$. After collection, the samples for analysis of cations were filtered $(0.45 \mu \mathrm{m})$, acidified $(\mathrm{pH}<2$, nitric acid), and refrigerated [41-44].

For $\delta^{18} \mathrm{O}$ and $\delta \mathrm{D}$ stable isotopes, samples were sealed in $20 \mathrm{~mL}$ amber bottles, capped without bubbles and kept refrigerated for analysis using cavity ring-down spectroscopy (Picarro) at the Environmental Isotope Laboratory (LIA, CEPAS|USP). For $\mathrm{d}^{15} \mathrm{~N}$, the technique involved: (i) sulfate precipitation with $\mathrm{BaCl}_{2}$; (ii) nitrate adsorption in an anion exchange resin column (Model AG1-X8, Bio-Rad); (iii) desorption by $\mathrm{HCl}$ flushing and precipitation as $\mathrm{AgNO}_{3}$ by $\mathrm{Ag}_{2} \mathrm{O}$ addition; and (iv) freeze-drying the purified $\mathrm{AgNO}_{3}$. The analysis was carried out at the University of Waterloo, Canada.

\subsection{Estimating Mass of Nitrate Beneath Urânia}

From the evaluation of all nitrate concentration data in the 2001 campaign iso-concentration maps, the relative thicknesses and areas of each nitrate concentration range $(\mathrm{mg} / \mathrm{L})$ were determined. The volume of each concentration range was associated with the respective nitrate concentration, resulting in the total mass value, in $\mathrm{kg}$.

To estimate the effective mass of nitrate, the total porosity of $15 \%$ was adopted from the results of the pumping tests, interpreted by the method of Neuman (1972) [45]. These calculations were made for the shallow zone (SZ), with an average thickness of $12 \mathrm{~m}$, and for the intermediate zone (IZ), with an average thickness of $48 \mathrm{~m}$. The total mass calculation was made considering:

Total mass $(\mathrm{kg})=$ area $\left(\mathrm{m}^{2}\right) \times$ average thickness $(\mathrm{m}) \times$ total porosity

\subsection{Numerical Model and Nitrate Transit Time Estimation}

The MODFLOW code [46], developed by the US Geological Survey (version 4.3), was used to solve the groundwater flow equation using the finite difference method. For the simulation of nitrate transport in the saturated zone, we used the MT3DMS code (version 5.2) [47] contained in the Visual MODFLOW package [48]. The flow model was calibrated by comparing the calculated hydraulic head data with the actual data measured in the field. Monitoring levels estimated the transient condition in three tubular wells with periodic measurements. There was no calibration for the transport model, and only possible scenarios were simulated based on data from the aquifer nitrate concentration maps. However, simulations were checked with the general behavior of the plume observed in the field. The map described in this nitrate distribution work was used as an initial condition

\section{Results and Discussion}

\subsection{Hydrogeological Conceptual Model of the Adamantina Aquifer}

The Adamantina Aquifer occurs throughout the urban area of Urânia. It is an unconfined and locally semi-confined aquifer. Recharge is the result of rain infiltration, with average values of $260 \mathrm{~mm} / \mathrm{y}$ [30], occurring from December to March, and due to leaks from the water and sewer mains [7]. The potentiometric surfaces follow the geomorphology of the area, where the groundwater dividers coincide with the surface watershed dividers. The groundwater flow lines converge to the Comprido and Matadouro streams, having an effluent character, with preferential direction from south to northeast. Figure 2 shows the potentiometric map of the Adamantina Aquifer, which was built from the hydraulic head measured in dug wells during the recharge period. Locally, the transmissivity $(\mathrm{T})$ and hydraulic conductivity $(\mathrm{K})$ are between $7 \times 10^{-3}$ and $9 \times 10^{-4} \mathrm{~m}^{2} / \mathrm{s}$, and $7 \times 10^{-5}$ and $8 \times 10^{-6} \mathrm{~m} / \mathrm{s}$, respectively, characterizing permeable and homogeneous sediments, with a flow velocity between $1.2 \times 10^{-5}$ and $6.2 \times 10^{-7} \mathrm{~m} / \mathrm{s}$, resulting from hydraulic gradients between $1.0 \%$ and $2.5 \%$ and specific yield (Sy) of 0.1-0.2. 
The aquifer was divided into the shallow (SZ), intermediate (IZ), and deep (DZ) zones according to the differences among the physicochemical characteristics of the waters in relation to the depth. SZ waters are captured by urban wells (up to $20 \mathrm{~m}$ deep) and range from chloride-nitrate-calcium to chloride-nitrate-sodium, with electric conductivity (EC) between 100 and $1500 \mu \mathrm{S} / \mathrm{cm}$, pH between 4.4 and 6.5, and with nitrate reaching $422 \mathrm{mg} / \mathrm{L}-\mathrm{NO}_{3}{ }^{-}$. The IZ is represented by tubular wells with depths between 20 and $60 \mathrm{~m}$, with magnesian calcium bicarbonate waters, $\mathrm{pH}$ close to 7, and EC between 100 to $400 \mu \mathrm{S} / \mathrm{cm}$, with decreasing concentrations of nitrate in depth. DZ is characterized by wells over $60 \mathrm{~m}$ deep, with sodium bicarbonate waters, $\mathrm{pH}$ between 8.5 and 11.0, and reduced calcium and magnesium concentrations with increased sodium (Figure 2), very low nitrate concentration, and EC below 100-200 $\mu \mathrm{S} / \mathrm{cm}$. Although the wells of greater depth have screens at various levels, and thus also capture waters of shallower portions, the hydraulic and hydrochemical data support this zoning.

The monthly and systematic collection of rainwater (2018-2019) allowed the establishment of the local meteorological line: $\delta^{2} \mathrm{H}=7.62 \delta^{18} \mathrm{O}+8.56$ (Figure 3), consistent with the groundwater-sampled overall works in Urânia.

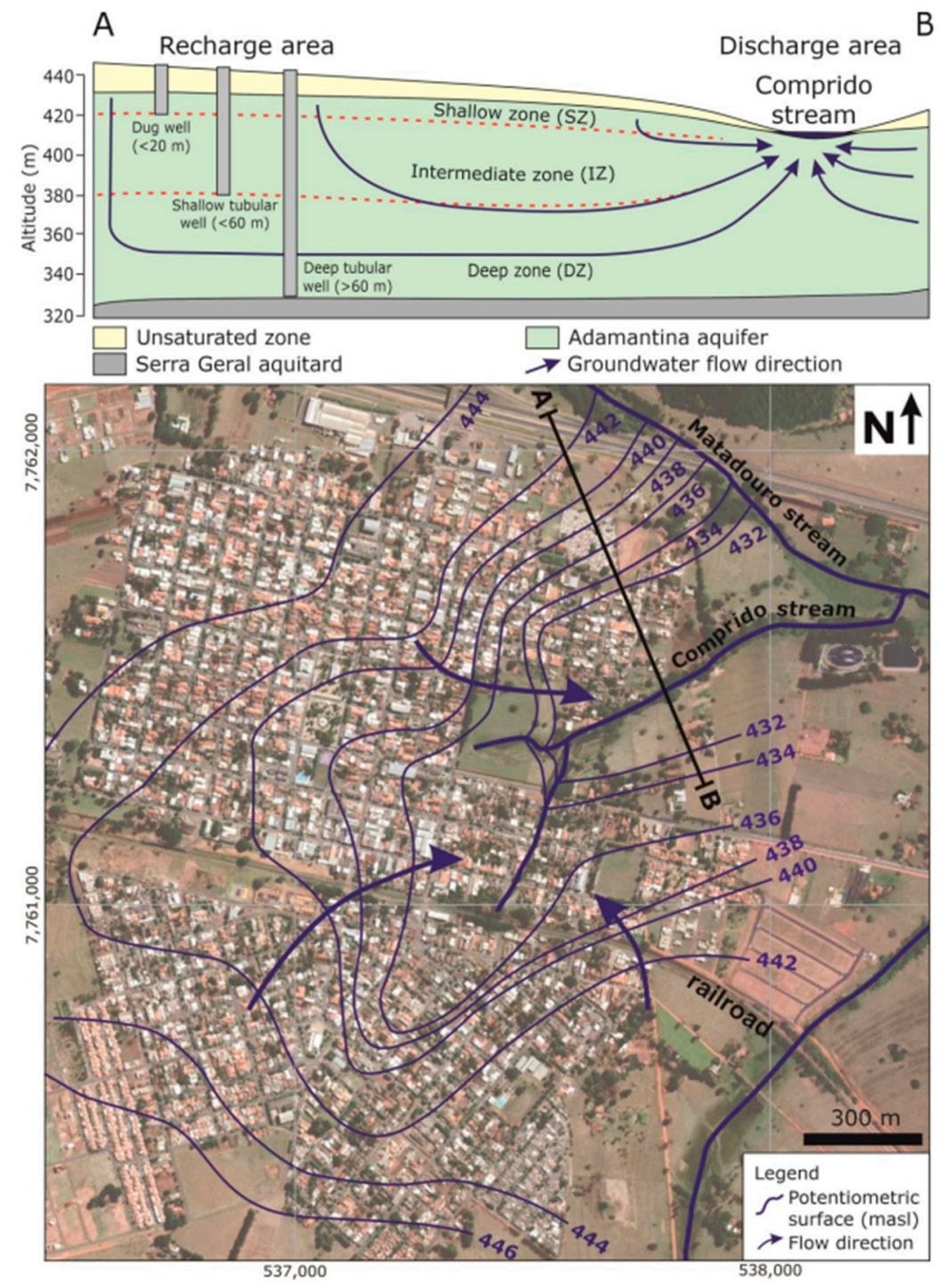

Figure 2. The Adamantina Aquifer's potentiometric surface map and conceptual hydrogeology cross-section. 


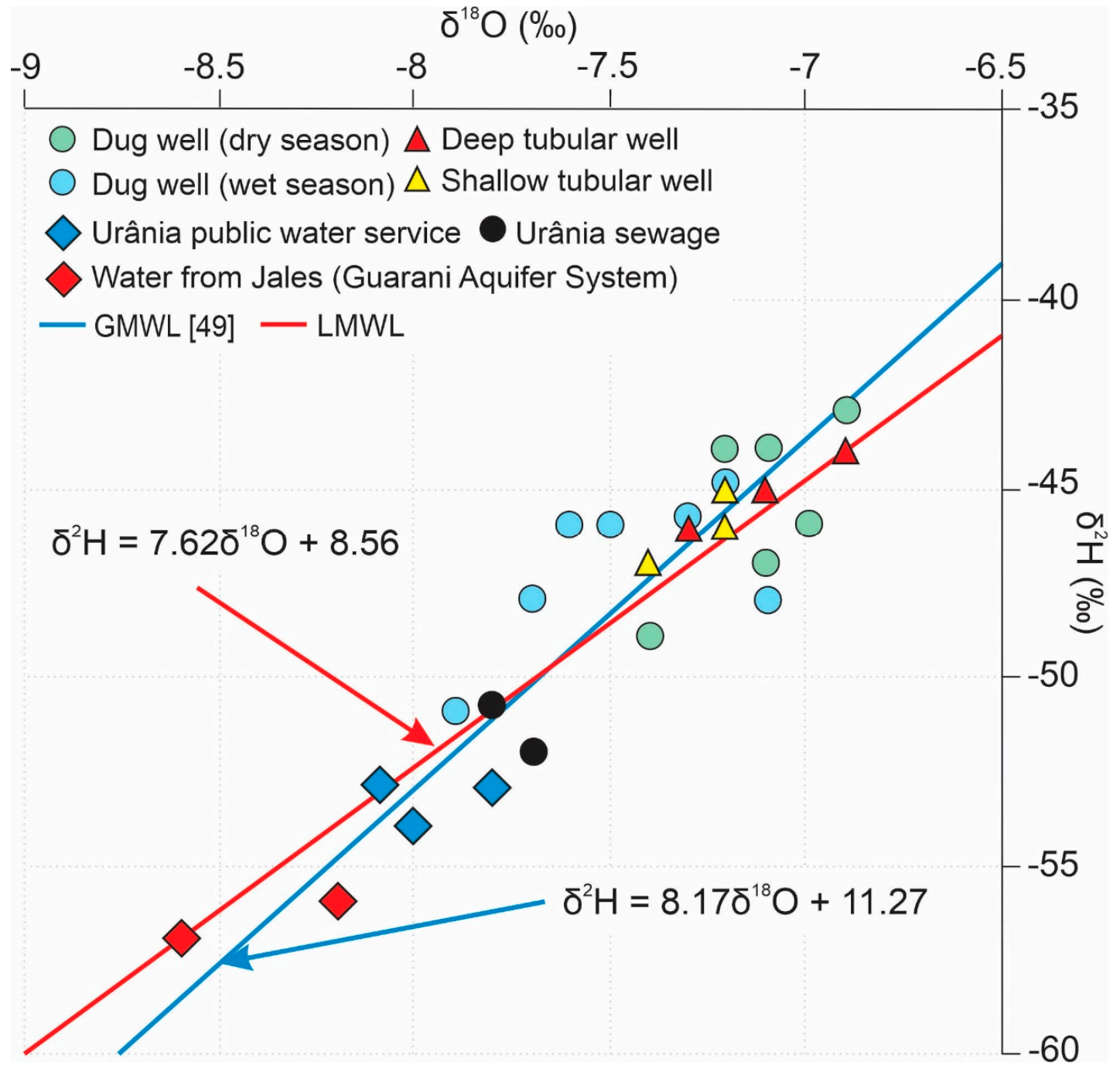

Figure 3. Stable isotope signature of groundwater in Urânia. Global Meteoric Water Line (GMWL) is based on Rozanski et al. (1993) [49], and de Local MWL was established in this study.

There are six groups of groundwater in Urânia (Table 2). Although there is a great dispersion and overlap of the results, it is possible to determine that the waters of the SZ (urban wells) have slightly more negative average signatures during the rainy season $\left(\delta^{18} \mathrm{O}=-7.5 \%\right.$ o $)$ than in the dry period (from $\delta^{18} \mathrm{O}=7.1 \%$ ), and the waters of the deepest wells, which extract water from IZ and DZ, equal these waters $\left(\delta^{18} \mathrm{O}=7.1 \%\right.$, from -6.8 to $-7.6 \%$ o). These results are consistent with the conceptual model, indicating an aquifer with rapid recharges during the summer and with more negative signature waters. That part of this recharge is the result of losses in the water and sewage network, which originates in the mixture of the Guarani Aquifer System $\left(\delta^{18} \mathrm{O}=-8 \%\right.$ o $)$, which is supplied from Jales $(14 \mathrm{~km})$ and with some waters of the deep zone of the Adamantina Aquifer $\left(\delta^{18} \mathrm{O}=-7.25 \%\right.$ o $)$ to a lesser extent. Sewage water has a slightly more positive isotopic signature $\left(\delta^{18} \mathrm{O}=-7.75 \%\right.$ o) than public water $\left(\delta^{18} \mathrm{O}=-8.0 \%\right.$ o $)$, suggesting that the population still uses water from the Adamantina Aquifer extracted from private tubular and urban wells. 
Table 2. Stable isotopic results for groundwater and sewage (\%o).

\begin{tabular}{|c|c|c|c|c|c|c|c|}
\hline \multirow[b]{2}{*}{ Well Type } & \multirow[b]{2}{*}{ ID } & \multicolumn{2}{|c|}{ Sep/2007 } & \multicolumn{2}{|c|}{ Sep/2008 } & \multicolumn{2}{|c|}{ Mar/2009 } \\
\hline & & $\delta^{18} \mathrm{O}$ & $\delta^{2} \mathbf{H}$ & $\delta^{18} \mathrm{O}$ & $\delta^{2} \mathbf{H}$ & $\delta^{18} \mathrm{O}$ & $\delta^{2} \mathbf{H}$ \\
\hline \multirow{9}{*}{ Dug wells } & PC-05 & - & - & -7.8 & -51 & -7.9 & -51 \\
\hline & PC-06 & -7.1 & -44 & -7.4 & -48 & -7.2 & -45 \\
\hline & PC -10 & -7.2 & -44 & -7.5 & -49 & -7.5 & -46 \\
\hline & PC -36 & -6.9 & -43 & 7.5 & -49 & - & - \\
\hline & PC -40 & -7.2 & -44 & -8.1 & -55 & -7.7 & -48 \\
\hline & PC -45 & -6.9 & -43 & -7.2 & -48 & -7.1 & -45 \\
\hline & PC -49 & -7.0 & -46 & - & - & - & - \\
\hline & PC -50 & -7.4 & -49 & -7.7 & -50 & -7.6 & -46 \\
\hline & PC -51 & -7.1 & - & -7.4 & -49 & -7.3 & -46 \\
\hline \multirow{9}{*}{ Shallow tubular wells } & PT-03 & -7.0 & -47 & - & - & - & - \\
\hline & PT-06 & -7.1 & -46 & -7.3 & -48 & -7.2 & -46 \\
\hline & PT-14 & -7.1 & -46 & -7.6 & -51 & -7.2 & -46 \\
\hline & PT-15 & -7.4 & -48 & -7.4 & -49 & -7.2 & -46 \\
\hline & PT-18 & -7.1 & -45 & -7.4 & -48 & -7.2 & -45 \\
\hline & PT-34 & -7.1 & -47 & -7.4 & -48 & -7.3 & -46 \\
\hline & PT-36 & -6.6 & -42 & -7.0 & -46 & - & - \\
\hline & PT-37 & -7.1 & -44 & -7.3 & -48 & -7.1 & -45 \\
\hline & PT-38 & -7.1 & -44 & -7.4 & -48 & -7.4 & -47 \\
\hline \multirow{4}{*}{ Deep tubular wells } & $\mathrm{PP}-02$ & -6.9 & -46 & -7.3 & -48 & -7.1 & -45 \\
\hline & $\mathrm{PP}-03$ & -7.0 & -45 & -7.3 & -47 & -6.9 & -44 \\
\hline & $\mathrm{PP}-04$ & -7.1 & -47 & -7.4 & -48 & -7.3 & -46 \\
\hline & $\mathrm{PP}-05$ & -7.5 & -48 & -7.6 & -49 & -7.5 & -48 \\
\hline Water from Jales (GAS) & & - & - & - & - & -8.2 & -56 \\
\hline Water from Jales (GAS) & & - & - & - & - & -8.6 & -57 \\
\hline Public water service (Urânia) & & -7.8 & -53 & -8.0 & -54 & -8.1 & -53 \\
\hline Sewage (Urânia) & & - & - & -7.7 & -52 & -7.8 & -51 \\
\hline
\end{tabular}

PC (dug well $<20 \mathrm{~m}$ ); PT (shallow tubular well $<60 \mathrm{~m}$ ); PP (deep tubular well $>60 \mathrm{~m}$ ).

\subsection{Evolution of Urban Occupation and Assessment of Potential Contamination}

Until 1959, Urânia was a district of the city of Jales (about $10 \mathrm{~km}$ to the southeast), during which time it had more than 17,000 inhabitants (including the current cities of Urânia, Santa Salete, and Aspásia). With the separation between 1993 and 1997, the municipality was established with an area of $210 \mathrm{~km}^{2}$. The reduction in agricultural importance, especially the cultivation of coffee, caused Urânia to lose its population over the years (Table 3). Urbanization began in the north and expanded to the south of the city. 
Table 3. Evolution of land use and occupation, with estimated demographic density values for Urânia [26].

\begin{tabular}{cccccccc}
\hline Period & $\mathbf{1 9 6 0}$ & $\mathbf{1 9 7 0}$ & $\mathbf{1 9 8 0}$ & $\mathbf{1 9 9 1}$ & $\mathbf{2 0 0 0}$ & $\mathbf{2 0 1 0}$ & $\mathbf{2 0 1 8}$ \\
\hline Urban population (hab) & 1708 & 5134 & 6498 & 7561 & 7063 & 7436 & 7502 \\
Rural population (hab) & 15,421 & 11,695 & 7012 & 4719 & 1759 & 1400 & 1158 \\
Total population (hab) & 17,129 & 16,829 & 13,510 & 12,280 & 8822 & 8836 & 8660 \\
Urbanization (\%) & 9.97 & 30.51 & 48.10 & 61.57 & 80.06 & 84.16 & 86.63 \\
Urban households & - & - & 1473 & 2029 & 2134 & 2568 & - \\
Rural households & - & - & 1371 & 1106 & 513 & 457 & - \\
Total households & 3000 & - & 2844 & 3135 & 2647 & 3025 & 3210 \\
Water supply (\%) & - & - & - & 97.88 & 98.13 & 99.26 & - \\
Sanitary sewage (\%) & Cesspool & 59 & 64 & 79 & 96.3 & 98.71 & - \\
Municipal area $\left(\mathrm{km}^{2}\right)$ & 357.84 & 357.84 & 357.84 & 357.84 & 209.27 & 209.27 & 209.27 \\
Urban area $\left(\mathrm{km}^{2}\right)$ & 0.72 & 1.19 & 1.47 & 1.65 & 2.14 & 2.40 & - \\
\hline
\end{tabular}

In the 1960s, water was supplied by dug wells, and domestic effluent was discharged into cesspits. In 1977, there was already a public water and sewage network collected from 59\% of the houses, but that was concentrated in the north and northwest areas of the city. In the 1980s, when $64 \%$ of the domestic effluent was collected, the implementation of the sewer mains began in the south and southwest areas, culminating in 1994 in the collection of $89 \%$ of the total effluent. In 1996, the final extension of the mains was built, which would reach $96 \%$ of the houses by 2001 and $99 \%$ today (Table 3, Figure 4).

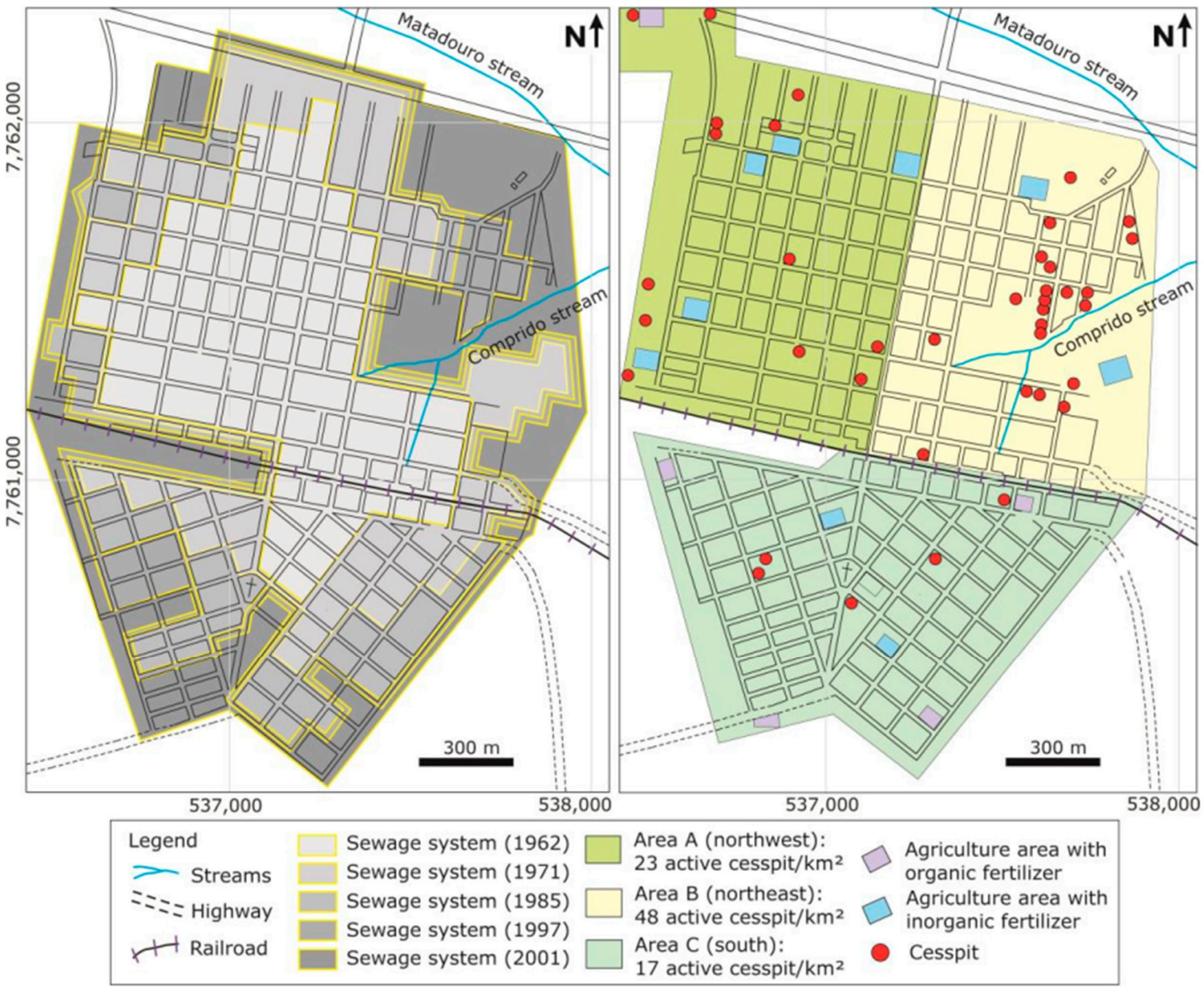

Figure 4. Urban area of Urânia showing the evolution of sewage system; and regions with different densities of cesspit per $\mathrm{km}^{2}$ with the locations of agricultural areas with types of fertilizers. 
The cesspits, which are used strictly in the city and extensively in rural areas today, have a diameter of up to $1.5 \mathrm{~m}$, and depths between 5 and $10 \mathrm{~m}$, often reaching the water table [8]. Usually, a cesspit receives all the wastewater from a residence, both from the bathrooms and the kitchen.

At the end of the 1990s, there were 72 cesspits located in the area with a sewage network, 57 of which were active, and 15 had been recently deactivated ( $<3$ years). From interviews with residents at that time, three regions with different densities of cesspit were identified, considering the form of urbanization and hydrogeological characteristic (Figure 4): area A (NW), with $23 \mathrm{cesspit} / \mathrm{km}^{2}$; area B $(\mathrm{NE} / \mathrm{E})$, with 48 cesspit $/ \mathrm{km}^{2}$; and area C (S), with 17 cesspit $/ \mathrm{km}^{2}$. Area A was the one that first received the sewer mains in the 1970s. In area B, complete coverage only occurred recently, and area $C$ is that where urbanization was, to a large extent, concomitant with the installation of the sanitation system. The cesspits were gradually deactivated, and there are records of at least 20 cesspit $/ \mathrm{km}^{2}$ in area B (NE/E) today.

Agricultural activity in the urban area was identified and mapped on 21 small properties, all of which used organic fertilizers (manure) and only eight of which also used inorganic fertilizers in 1990s. This profile has not changed much over the years (Figure 4).

\subsection{Chemical and Physicochemical Analysis}

The SZ presents predominantly calcium-chlorinate-nitrate and mixed water. In IZ, the water is calcium bicarbonate and calcium bicarbonate (nitrate), with variable impacts of contamination by domestic wastewater (Figure 5). In the DZ, the water is calcium and sodium bicarbonate. The concentrations of sodium, chlorides, and nitrate decrease, followed by sulfate and potassium, and those of calcium, bicarbonate, and $\mathrm{pH}$ increase from SZ to IZ, showing a clear stratification of these ions. The average concentration of chloride in $S Z$ was $19.68 \mathrm{mg} / \mathrm{L}$ and decreased to $14.26 \mathrm{mg} / \mathrm{L}$ in IZ, and the nitrate of $140 \mathrm{mg} / \mathrm{L}-\mathrm{NO}_{3}{ }^{-}$in SZ changed to $81 \mathrm{mg} / \mathrm{L}-\mathrm{NO}_{3}{ }^{-}$in IZ, which may indicate denitrification. Although dilution by rain plays an important role, as noted by the rapid variation in the signature of ${ }^{18} \mathrm{O}$, which becomes more negative after periods of rain $(-0.35 \%$ o).

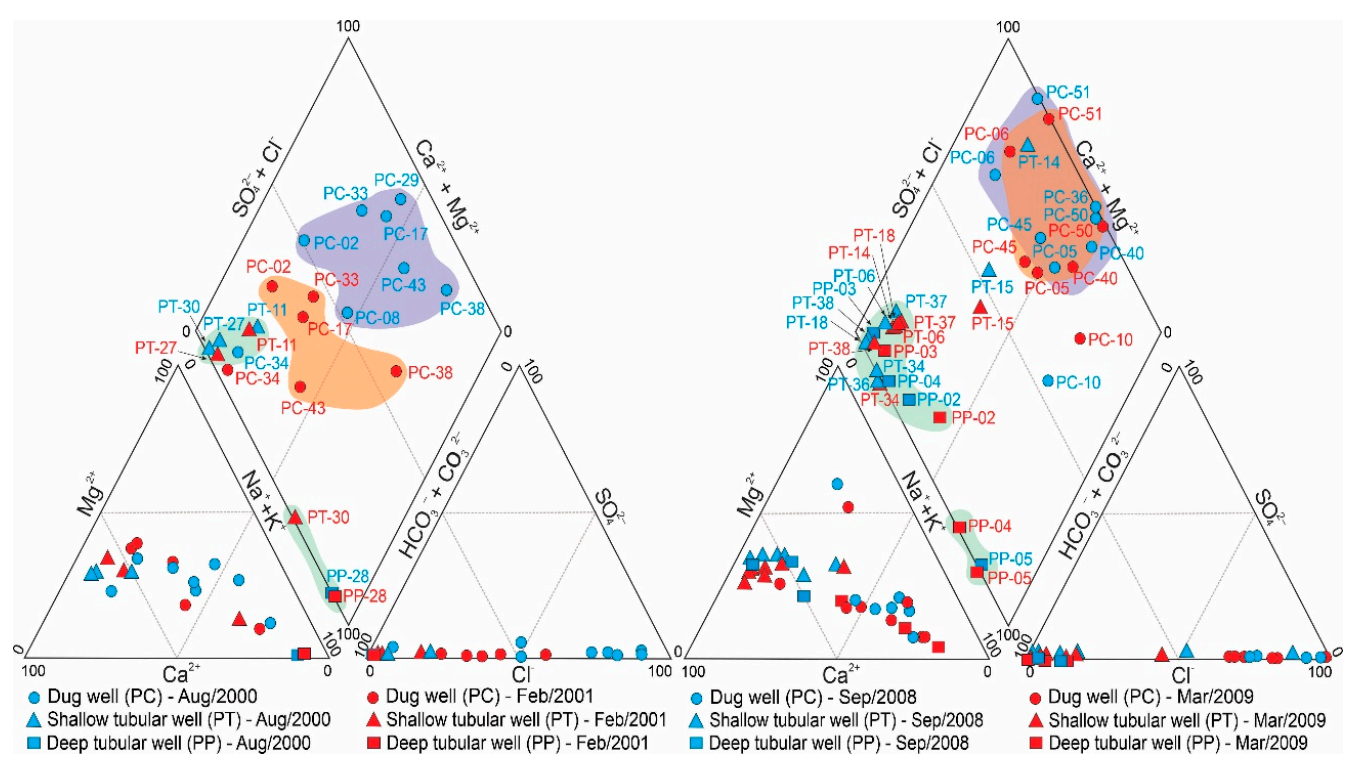

Figure 5. Geochemical evolution in the waters of dug wells (PC), shallow tubular wells (PT) and deep tubular wells (PP), related to the shallow zone (SZ), the intermediate zone (IZ), and the deep zone (DP), respectively.

The concentrations of nitrate and chloride varied in the SZ over the course of a hydrological year due to the recharge of the aquifer that affects SZ more than the other deeper zones (Figure 5). After the period of rain, the water level increases by $2-3 \mathrm{~m}$. 
The intensity of the rains also influences changes in the water composition of the SZ wells. In the summer of 2000-2001, for example, rainfall accumulated in the two months preceding the groundwater sampling (January and February, $521 \mathrm{~mm}$ ) changing the hydrochemical signature of SZ waters from sodium chloride to sodium bicarbonate, while the 2008-2009 summer rains (February and March, $241 \mathrm{~mm}$ ) did not alter this signature (Figure 5).

Calcium and sodium bicarbonate water, with low nitrate $\left(<1 \mathrm{mg} / \mathrm{L}_{-} \mathrm{NO}_{3}{ }^{-}\right)$and chloride $(4 \mathrm{mg} / \mathrm{L})$, indicate that there is a small impact of urban contamination on the DZ and that this is the natural geochemical signature. In DZ, there is an increase in $\mathrm{pH}$ and sodium, accompanied by a reduction in calcium and magnesium concentrations through cation exchange mechanisms [50].

Another characteristic is that in both SZ and IZ, an oxidizing hydrochemical environment predominates, providing the existence of nitrate abundantly and stably. Waters with nitrite, ammonium (except in three wells), ammonia, and organic nitrogen are virtually non-existent. Dissolved organic carbon (DOC) was detected between $0.89 \mathrm{mg} / \mathrm{L}$ and $0.29 \mathrm{mg} / \mathrm{L}$. Eh values range from $290 \mathrm{mV}$ to $721 \mathrm{mV}$, showing relative homogeneity throughout all sampling campaigns, both between SZ and IZ and between dry and wet seasons. These results corroborate those observed in other regional studies of the Adamantina Aquifer, although it is recognized that there are more specific variations associated with the hydraulic heterogeneity of the aquifer, and where denitrification may occur [51]. Additionally, $\delta^{15} \mathrm{~N}$ results did not show variations in their signatures between contaminated waters from SZ $\left(\delta^{15} \mathrm{~N}\right.$ from +8.74 to $+11.13 \%$ o $)$ and $\mathrm{IZ}\left(\delta^{15} \mathrm{~N}\right.$ from +7.75 to $\left.+11.93 \%\right)$, not indicating denitrification processes, which would enrich the $\delta^{15} \mathrm{~N}$ of the nitrate.

Regarding the territorial distribution, the highest concentrations of nitrate $(>80 \mathrm{mg} / \mathrm{L})$, chloride (mean value $20 \mathrm{mg} / \mathrm{L}$ ) and EC $(315 \mu \mathrm{S} / \mathrm{cm}$ ) were detected in area B (Figure 6), close to the Comprido stream, where the water table is shallow, and where there is the highest density of cesspit still active or recently abandoned. In this location, IZ has low concentrations of nitrate, confirming the notion that the Comprido stream is the discharge of deeper levels of the aquifer (DZ). In area A (NW), the oldest occupied region (before 1962), nitrate is widely distributed throughout the urban area, especially in IZ. In area C, south of the city, there is less contamination in both SZ and IZ (Figure 6).
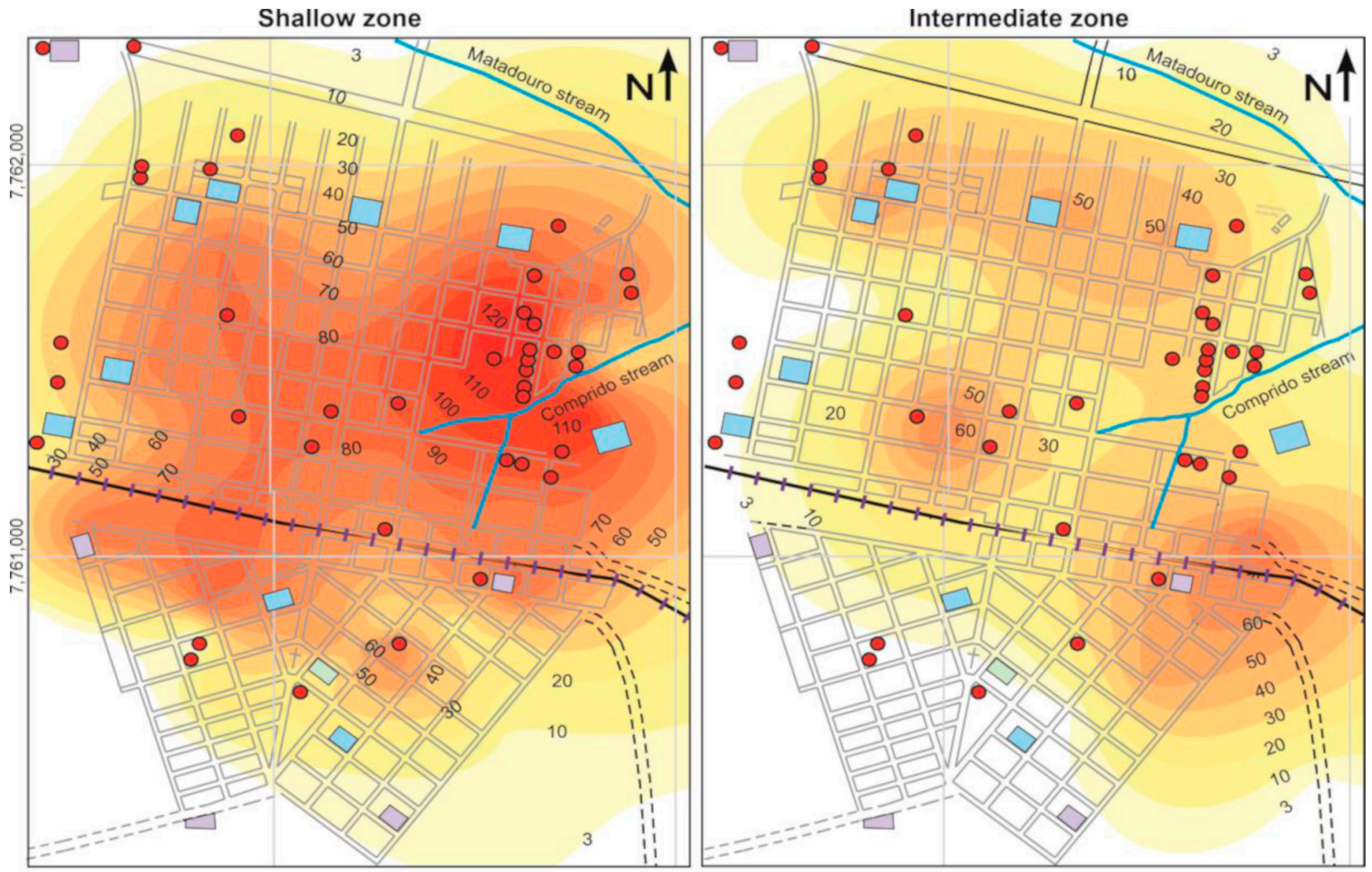

Figure 6. Cont. 


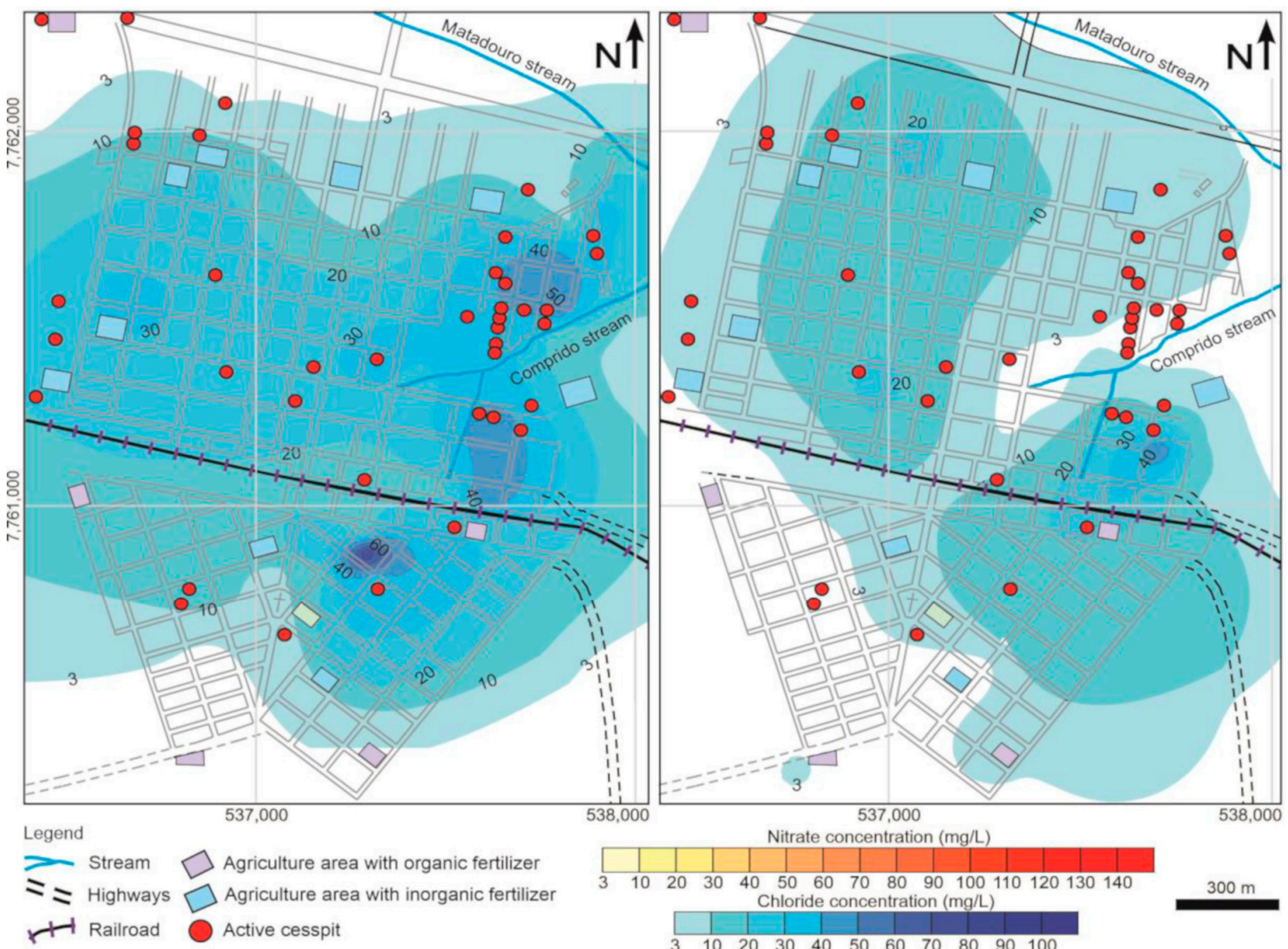

Figure 6. Nitrate (top) and chloride (bottom) isoconcentration maps indicating that the values are higher in the shallow (SZ) than the intermediate (IZ) zone.

\subsection{Mass of Nitrate Beneath Urânia}

From the concentration distribution maps (Figure 6) and considering aquifer geological characteristics, the remaining nitrate mass was calculated for the shallow and intermediate zones of the Adamantina Aquifer under the city of Urânia (Table 4). A total of $731 \mathrm{~kg}-\mathrm{NO}_{3}{ }^{-}$is distributed $59 \%$ in the IZ, and 31\% in SZ. The results indicate that, although SZ is more contaminated, there is larger $\mathrm{NO}_{3}{ }^{-}$mass content at the IZ due to its greater thickness.

Table 4. Nitrate mass values $(\mathrm{kg})$ in shallow and intermediate zones.

\begin{tabular}{|c|c|c|c|c|}
\hline \multicolumn{2}{|c|}{$\mathrm{NO}_{3}{ }^{-}$Concentration $(\mathrm{mg} / \mathrm{L})$} & $\begin{array}{l}\text { Area } \\
\left(\mathrm{m}^{2}\right)\end{array}$ & $\begin{array}{c}\text { Average } \\
\text { Thickness (m) }\end{array}$ & $\begin{array}{c}\text { Total Mass } \\
(\mathbf{k g})\end{array}$ \\
\hline \multirow{13}{*}{ Shallow zone } & 130 & 2.7 & 12 & 0.6 \\
\hline & 120 & 14.3 & 12 & 3.1 \\
\hline & 110 & 43.8 & 12 & 8.7 \\
\hline & 100 & 89.6 & 12 & 16.1 \\
\hline & 90 & 125.7 & 12 & 20.4 \\
\hline & 80 & 392.4 & 12 & 56.5 \\
\hline & 70 & 389.9 & 12 & 49.1 \\
\hline & 60 & 267.2 & 12 & 28.9 \\
\hline & 50 & 306.1 & 12 & 27.6 \\
\hline & 40 & 358.6 & 12 & 25.8 \\
\hline & 30 & 455.8 & 12 & 24.6 \\
\hline & 20 & 627.3 & 12 & 22.6 \\
\hline & 10 & 840.0 & 12 & 15.1 \\
\hline \multicolumn{2}{|c|}{ Total } & 3913.2 & - & 299.0 \\
\hline
\end{tabular}


Table 4. Cont.

\begin{tabular}{ccccc}
\hline $\mathbf{N O}_{3}-$ Concentration $\left.\mathbf{( m g} / \mathbf{L}\right)$ & $\begin{array}{c}\text { Area } \\
\left(\mathbf{m}^{\mathbf{2}}\right.\end{array}$ & $\begin{array}{c}\text { Average } \\
\text { Thickness } \mathbf{( m )}\end{array}$ & $\begin{array}{c}\text { Total Mass } \\
\mathbf{( k g )}\end{array}$ \\
\hline \multirow{6}{*}{ Intermediate zone } & 80 & - & - & - \\
& 70 & 11.3 & 48 & 5.7 \\
& 60 & 55.0 & 48 & 23.8 \\
& 50 & 150.0 & 48 & 54.0 \\
& 30 & 388.8 & 48 & 112.0 \\
& 20 & 563.1 & 48 & 121.6 \\
& 10 & 475.0 & 48 & 68.4 \\
& & 646.3 & 48 & 46.5 \\
\hline
\end{tabular}

\subsection{Numerical Model and Nitrate Transit Time Estimation}

The simulation of contamination scenarios was based on the distribution of nitrate in the city of Urânia in 2001, using the Modflow code, which discretized the area into 89 rows, 93 columns, and seven layers, totaling 8277 cells, with minimum horizontal sizes of $10 \times 10 \mathrm{~m}$. The calibration was performed by trial and error, and the model was calibrated with an RMS error of $8 \%$. Some scenarios included pumping wells, which have been running continuously for up to 100 years. The transport model was MT3D, which considered only longitudinal and transverse hydraulic dispersion, because, to date, there is no evidence of extensive denitrification in the area.

The modeled area was divided into ten zones with different hydraulic conductivities in the range of $6 \times 10^{-8} \mathrm{~m} / \mathrm{s}$ and $3 \times 10^{-5} \mathrm{~m} / \mathrm{s}$. Total porosity was $10-15 \%$, and effective porosity was $7-10 \%$ (Adamantina Aquifer). It was assumed that the aquifer was horizontally isotropic, and the vertical hydraulic conductivity was ten times lower than the horizontal. The basalt of the Serra Geral Formation was considered a regional aquitard, with a hydraulic conductivity of $6 \times 10^{-10} \mathrm{~m} / \mathrm{s}$. The model had two different recharges: the first associated with the city of $230 \mathrm{~mm} / \mathrm{y}$, and the rural one, with $183 \mathrm{~mm} / \mathrm{y}$, with no variation in time.

The modeled initial concentration (Co) in all cases was established as $\mathrm{Co}=100 \mathrm{mg} / \mathrm{L}_{-} \mathrm{NO}_{3}{ }^{-}$ (simulating $100 \%$ of the load), and the model results in a fraction of that value (C/Co). Various scenarios were modeled (Table 5, Figure 7), and in some cases, the sensitivity of the model to the variation in longitudinal dispersivity $(\alpha \mathrm{L})$ and the pumping of existing wells in 2001 was also simulated (the year with the highest number of active wells in the city). Flow and transport modeling start in year zero. As the main source of nitrate was the leakage from the sewage network, it did not occur homogeneously or in a single moment. It must be considered that the entire sewage network in the city was built with ceramic pipes, subject to leaks [18]. After the 1990s, these were replaced by plastic tubes, which have few leaks, as observed in the south of the city (Area C).

Thus, the numerical modeling considered here, despite having a relationship with the aquifer's reality, is an exercise in understanding the evolution of the contaminating plume and supporting decision making for territorial occupation and the protection of urban groundwater.

Simulations 1, 2, and 3 (Figure 7) show a continuous source of contamination throughout the area, representing leakage from the sewer network and the effect of hydraulic dispersion, with estimated values of $107.9 \mathrm{~m}$ longitudinal dispersion $(\alpha \mathrm{L})$ and transverse dispersion of $10.79 \mathrm{~m}$. The results in the three situations are regionally very similar. The pumping effect can be seen by comparing simulations 2 and 4 , where the contaminant mass was extracted by pumping the wells that also caused a smaller horizontal advance of the contaminating plume, but with greater vertical movements of the nitrate (Table 5 and Figure 7). 
Table 5. Simulated nitrate distribution scenarios in the Adamantine Aquifer in Urânia.

\begin{tabular}{|c|c|c|c|c|}
\hline Simulation & Nitrate Contamination & Pumping & Dispersion & $\begin{array}{l}\text { Comments on the Extent of the Estimated Contamination } \\
\text { Plume and Dispersion for Shallow Zone (SZ), Intermediate } \\
\text { Zone (IZ), and Deep Zone (DZ) }\end{array}$ \\
\hline 1 & $100 \%$ overall urban area for 100 years & No & No & $\begin{array}{l}\text { SZ: } 100 \% \text { of the plume reaches in } 1 \text { year. } \\
\text { IZ: } 98 \% \text { of the plume reaches in } 5 \text { year. } \\
\text { DZ: } 70 \% \text { of the plume reaches in } 10 \text { year. }\end{array}$ \\
\hline 2 & $100 \%$ overall urban area for 100 years & No & Longitudinal $10.79 \mathrm{~m}$ & Idem. \\
\hline 3 & $100 \%$ overall urban area for 100 years & No & Longitudinal $107.9 \mathrm{~m}$ & Idem. \\
\hline 4 & $100 \%$ overall urban area for 100 years & Yes & Longitudinal $10.79 \mathrm{~m}$ & $\begin{array}{l}\text { SZ: } 99 \% \text { of the plume reaches the zone. } \\
\text { IZ: } 85 \% \text { of the plume reaches the zone. } \\
\text { DZ: } 41 \% \text { of the plume reaches the zone. } \\
\text { No major impact of dispersion. }\end{array}$ \\
\hline 5 & $\begin{array}{l}100 \% \text { overall urban area for } 10 \text { years } \\
\text { only, and } 100 \% \text { efficient sewer network }\end{array}$ & No & Longitudinal $10.79 \mathrm{~m}$ & $\begin{array}{l}\text { SZ: } 65 \% \text { of the plume in } 10 \text { years and } 0 \% \text { in } 100 \text { years. } \\
\text { IZ: } 27 \% \text { of the plume in } 23 \text { years and } 1 \% \text { in } 100 \text { years. } \\
\text { DZ: } 15 \% \text { of the plume in } 72 \text { years and } 11 \% \text { in } 100 \text { years. } \\
\text { Significant drop in concentrations after source ceased. In } 10 \text { years } \\
\text { contamination problem (SZ and IZ) would be solved. }\end{array}$ \\
\hline 6 & $\begin{array}{l}100 \% \text { overall urban area for } 10 \text { years } \\
\text { only, and } 100 \% \text { efficient sewer network }\end{array}$ & Yes & Longitudinal $10.79 \mathrm{~m}$ & $\begin{array}{l}\text { SZ: } 84 \% \text { of the plume in } 10 \text { years and } 0 \% \text { in } 100 \text { years. } \\
\text { IZ: } 41 \% \text { of the plume in } 12 \text { years and } 1 \% \text { in } 100 \text { years. } \\
\text { DZ: } 11 \% \text { of the plume in } 29 \text { years and } 1 \% \text { in } 100 \text { years. } \\
\text { Significant reduction in concentrations after source ceased } \\
\text { (greater dilution and increase in the vertical gradient) }\end{array}$ \\
\hline 7 & $\begin{array}{l}100 \% \text { for the cesspits registered for } \\
100 \text { years [7] }\end{array}$ & No & No & $\begin{array}{l}\text { SZ and IZ: } 13 \% \text { of the plume will reach these areas. } \\
\text { DZ: } 6 \% \text { of the plume will reach the zone. } \\
\text { No increase in nitrate concentrations in the aquifer in a fraction } \\
\text { greater than } 13 \% \text { of the initial contamination. }\end{array}$ \\
\hline 8 & $\begin{array}{l}100 \% \text { for the cesspits registered for } \\
100 \text { years [7] }\end{array}$ & Yes & No & $\begin{array}{l}\text { SZ: } 5 \% \\
\text { IZ: } 6 \% \\
\text { DZ: } 4 \%\end{array}$ \\
\hline 9 & $\begin{array}{c}100 \% \text { (one cell with source and one } \\
\text { not) for } 100 \text { years }\end{array}$ & No & No & $\begin{array}{l}\text { SZ: } 44 \% \\
\text { IZ: } 48 \% \\
\text { DZ: } 31 \%\end{array}$ \\
\hline 10 & $\begin{array}{l}100 \% \text { (one cell with source and one } \\
\text { not) for } 100 \text { years }\end{array}$ & Yes & No & $\begin{array}{l}\text { SZ: } 44 \% \\
\text { IZ: } 47 \% \\
\text { DZ: } 25 \%\end{array}$ \\
\hline
\end{tabular}



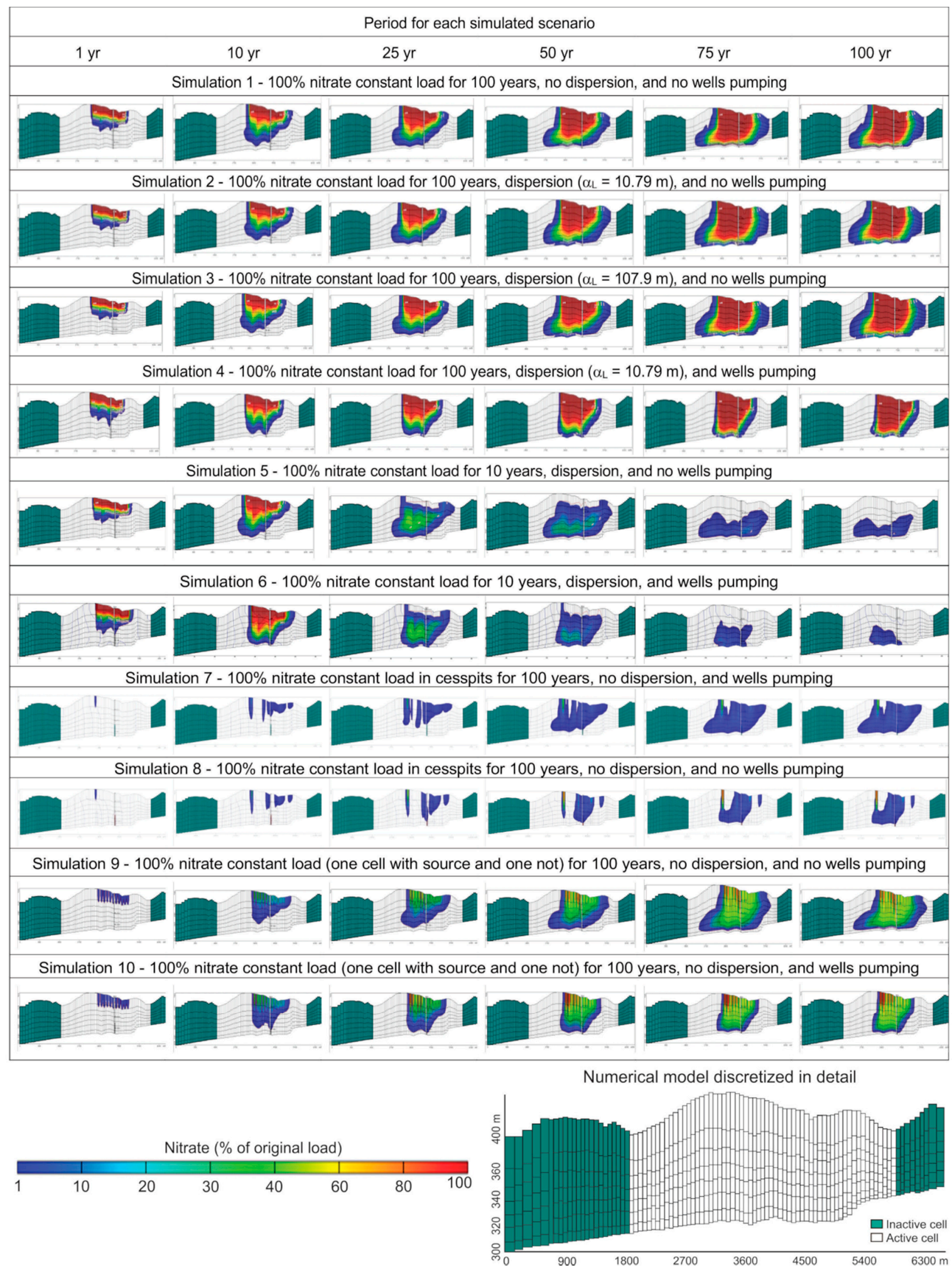

Figure 7. Simulated nitrate distribution scenarios in the Adamantina Aquifer in Urânia.

Simulations 5 and 6 consider that the source of contamination ceases, that is, there is no more leakage from the sewer main and without the presence of cesspits after 10 years of activity. It appears that in 40 years (or 30 after the source ceases), there is still $20 \%$ of the DZ concentration and that some contaminating mass would be present after 90 years, however, in low concentration. The pumping of 
wells is effective a great help in reducing the volume and concentrations of the plume horizontally and vertically.

Simulations 7 and 8 reproduce what it would be like if the active cesspits in 2000 continued to operate, indicating that, although there was some local impact, the plume concentrations would never reach more than $10 \%$ of the initial concentration, showing that they do not support a plume of the dimensions of the plumes observed today.

In simulations 9 (without pumping) and 10 (with pumping), the area impacted by the contaminating load was reduced by $50 \%$ (one cell with a source and another without), showing that the repair of the sewer network would not have to be complete ( $100 \%$ efficient) to reduce the problems arising from its leakage significantly.

These simulations 9 and 10 show that the cause of the contamination observed in Urânia was due to the combination of a large infiltration of nitrogen through the cesspits, from the beginning of the urban occupation until the 1970s, and after the 1990s, by leakage of the sewage network.

\section{Conclusions}

The groundwater of the Adamantina Aquifer in Urânia is contaminated by nitrate in its shallow (up to $20 \mathrm{~m}$ deep, SZ) and intermediate (20-60 m deep, IZ) zones, despite the sewer network that currently covers $98 \%$ of the city. The contamination mainly occurs in the north-central part of the city (Areas A and B), the region of the first settlements, and where the sewer mains dates from the 1970s. In the southern region of the city (Area C), the sewer network was installed concurrently with the development of the neighborhood after the 1990s, and nitrate concentrations are lower $(<3 \mathrm{mg} / \mathrm{L})$ and located in the shallow aquifer. It is estimated that there are more than $731 \mathrm{~kg}$ of nitrate $\left(\mathrm{NO}_{3}{ }^{-}\right)$in the entire aquifer, with $300 \mathrm{~kg}$ in shallow zone and the rest in intermediate zone.

The origin of nitrate contamination in Urânia is associated with residential domestic wastewater, which, prior to the 1970s, was fully infiltrated into cesspits. Even though the sewage network was installed more than 40 years ago, the nitrate contamination plume is still persistent. Numerical flow and transport modeling have shown that the time required for a plume of a persistent contaminant to be completely eliminated from the aquifer is more than 100 years, and that it is possible to achieve water potability for nitrate in $30-40$ years $\left(<45 \mathrm{mg} / \mathrm{L}-\mathrm{NO}_{3}{ }^{-}\right)$, assuming that the source is completely removed. However, a strong correlation observed between recharge rates and variations in the nitrate concentration in the shallow zone suggests that this is a very dynamic system, and that there are still active sources of contamination. Including the still operational cesspits as nitrate sources in the aquifer's numerical simulations, the results indicate that they are not sufficient to sustain the contamination observed today (2020). Therefore, this study suggests that leaks from the sewage network, resulting from low maintenance, are the current primary sources of nitrogen to the aquifer and can sustain the persistent nitrate concentrations of the Adamantina Aquifer.

Author Contributions: Conceptualization, R.H.; methodology, formal analysis, investigation, R.H., F.C., A.B., C.M., C.H.M., C.V., R.B.; data curation: C.H.M., P.G., R.T.; writing-original draft preparation R.H.; writing-review and editing: C.H.M., P.G., R.T., M.C.R. All authors have read and agreed to the published version of the manuscript.

Funding: This research was funded by CNPq (Process 422501/2016-6) and FAPESP (Processes 2019/20544-1, 2015/03806-1, 2007/51992-2).

Acknowledgments: The authors would like to thank the employees of SABESP (Companhia de Saneamento Básico do Estado de São Paulo) Cesar Vieira, Benedito Filho, and Antônio Rodrigues da Grela Filho (Dalua), of the Municipality of Urânia, as well as Ramon Aravena (Environmental Isotope Laboratory, University of Waterloo), and members of the Physical Models Laboratory (LAMO|CEPAS) of the Groundwater Research Center (CEPAS|USP) of the Institute of Geosciences of the University of São Paulo.

Conflicts of Interest: The funders had no role in the design of the study; in the collection, analyses, or interpretation of data; in the writing of the manuscript, or in the decision to publish the results. 


\section{References}

1. WHO-World Health Organization. Nitrate and Nitrite in Drinking-Water: Background Document for Development of WHO Guidelines for Drinking-water Quality; WHO Press: Geneva, Switzerland, 2011; p. 23. Available online: https://www.who.int/water_sanitation_health/dwq/chemicals/nitratenitrite2ndadd.pdf (accessed on 19 September 2020).

2. United States Environmental Protection Agency US EPA. Ground Water Sampling Workshop-A Workshop Summary, Dallas, TX, USA, 30 November-2 December 1993; EPA: Washington, DC, USA; p. 126.

3. Singh, B.; Sekhon, G.S. Nitrate pollution of groundwater from farm use of nitrogen fertilizer-A review. Agric. Environ. 1979, 4, 207-225. [CrossRef]

4. Dahan, O.; Babad, A.; Lazarovitch, N.; Russak, E.E.; Kurtzman, D. Nitrate leaching from intensive organic farms to groundwater. Hydrol. Earth Syst. Sci. 2014, 18, 333-341. [CrossRef]

5. Bahrami, M.; Zarei, A.R.; Rostami, F. Temporal and spatial assessment of groundwater contamination with nitrate by nitrate pollution index (NPI) and GIS (case study: Fasarud Plain, southern Iran). Environ. Geochem. Health 2020, 1-12. [CrossRef]

6. Sahoo, P.K.; Kim, K.; Powell, M.A. Managing Groundwater Nitrate Contamination from Livestock Farms: Implication for Nitrate Management Guidelines. Curr. Pollut. Rep. 2016, 2, 178-187. [CrossRef]

7. Cagnon, F.A. Origin and Hydrochemistry of Nitrate in the Groundwater of the Adamantina Aquifer in Urânia, SP [Port.]. Master's Thesis, University of de São Paulo, São Paulo, Brazil, 2003.

8. Varnier, C.; Hirata, R.; Aravena, R. Examining nitrogen dynamics in the unsaturated zone under an inactive cesspit using chemical tracers and environmental isotopes. Appl. Geochem. 2017, 78, 129-138. [CrossRef]

9. Lerner, D.N. Groundwater recharge in urban areas. In Atmospheric Environment Part B. Urban Atmosphere; Elsevier: Amsterdam, The Netherlands, 1990; Volume 24, pp. 29-33.

10. Foster, S.S.D.; Hirata, R.; Gomes, D.; D’Elia, M.; Paris, M. Groundwater Quality Protection: A Guide for Water Utilities, Municipal Authorities, and Environment Agencies; The World Bank: Washington, DC, USA, 2002.

11. Marques, C.H.G.; Terada, R.; Galvão, P.; Hirata, R. Nitrate contamination temporal and spatial evolution of the Urânia urban aquifer [Port.]. Águas Subterr. 2019, 33, 258-269. [CrossRef]

12. Price, M.; Reed, D.W. The influence of mains leakage and urban drainage on groundwater levels beneath conurbations in the UK. Proc. Inst. Civ. Eng. 1989, 86, 31-39. [CrossRef]

13. Lawrence, A.R.; Barker, J.A.; Boonyakarnkul, T.; Chanvaivit, S.; Nagesuwan, P.; Sirirat, P.; Stuart, M.E.; Thandat, P.; Varathan, P. Impact of urbanization on groundwater: Hat Yai. Thailand. Br. Geol. Sur. (BGS) 1994. Available online: http://cidbimena.desastres.hn/pdf/eng/doc5925/doc5925-indice.pdf (accessed on 24 September 2020).

14. Ortiz, C.R.F.; Díaz-Delgado, C.; Téllez, M.H.; Alberich, M.V.E. Demanda hídrica urbana en México: Modelado espacial con base en sistemas de información geográfica. Interciencia 2013, 38, 17-25.

15. Yang, Y.; Lerner, D.N.; Barrett, H.M.; Tellam, J.H. Quantification of groundwater recharge in the city of Nottingham, UK. Environ. Geol. 1999, 38, 183-198. [CrossRef]

16. Morris, B.L.; Darling, W.G.; Cronin, A.A.; Rueedi, J.; Whitehead, E.J.; Gooddy, D.C. Assessing the impact of modern recharge on a sandstone aquifer beneath a suburbof Doncaster, UK. Hydrogeol. J. 2006, 14, $979-997$. [CrossRef]

17. Foster, S.; Hirata, R.; Garduño, H. Urban Groundwater Use Policy_Balancing the Benefits and Risks in Developing Nations. GW-MATE Strategic Overview Series 3; The World Bank: Washington, DC, USA, 2010. Available online: www.worldbank.org/gwmate (accessed on 24 September 2020).

18. Hirata, R.; Foster, S.; Oliveira, F.R. Urban Groundwater in Brazil: Assessment for a Sustainable Management [Port.], 1st ed.; Instituto de Geociências e FAPESP: São Paulo, Brazil, 2015; p. 112.

19. Campos, H.; Hirata, R.; Rocha, G.; Mistreta, G. Nitrate Origin and Occurrence in Aquifers of the State of São Paulo, Brazil [Port.]. In Congresso Latino Americano de Hidrogeologia Subterránea, 2., Santiago; ALHSUD: Santiago, Chile, 1994; Volume 1, pp. 111-126. Available online: http://alhsud.com/principal/index.html (accessed on 24 September 2020).

20. Sekhon, G.S. Fertilizer-N use efficiency and nitrate pollution of groundwater in developing countries. J. Contam. Hydrol. 1995, 20, 167-184.

21. Galvão, P.; Hirata, R.; Halihan, T.; Terada, R. Recharge sources and hydrochemical evolution of an urban karst aquifer, Sete Lagoas, MG, Brazil. Environ. Earth Sci. 2017, 76, 159. [CrossRef] 
22. Simonato, M. Electricity Cost of Pumping Wells in Areas of Intense Exploitation: Study Case of São José do Rio Preto (SP) [Port.]. Master's Thesis, University of de São Paulo, São Paulo, Brazil, 2013.

23. Bertolo, R.A.; Bourrote, C.; Hirata, R.; Marcolan, L.N.O.; Sracek, O. Geochemistry of natural chromium occurrence in a sandstone aquifer in Bauru Basin, São Paulo State, Brazil. App. Geochem. 2011, 26, 1353-1363. [CrossRef]

24. Varnier, C.; Iritani, M.; Viotti, M.; Oda, G.H.; Ferreira, L.M.R. Nitrate in groundwater of the Bauru Aquifer System, Marilia Municipality urban area (SP) [Port.]. Rev. Inst. Geol. 2010, 31, 1-21. [CrossRef]

25. Procel, S.P. Nitrate Contamination and Its Relationship with Urban Growth in the Bauru Aquifer System in Presidente Prudente (SP) [Port.]. Master's Thesis, University of de São Paulo, São Paulo, Brazil, 2011.

26. IBGE-Instituto Brasileiro de Geografia e Estatística Home Page. Available online: http://www.ibge.gov.br/ cidadesat/topwindow.htm?1 (accessed on 30 March 2016).

27. Departamento de Águas e Energia do Estado de São Paulo. Study of Groundwater; Administrative Regions 7, 8 e 9 (Bauru, São José do Rio Preto e Araçatuba) [Port.]; ENCO: São Paulo, Brazil, 1976.

28. Sracek, O.; Hirata, R. Geochemical and stable isotopes evolution of the Guarani Aquifer System in the State of São Paulo, Brazil. Hydrogeol. J. 2002, 10, 643-655. [CrossRef]

29. Rocha, G.A.; Bertachini, A.C.; Campos, H.C.N.S.; Caixeta, J.B. Attempting to zoning the hydraulic and hydrochemical characteristics of the Bauru Aquifer [Port.]. In Geology and Hydrogeology Meeting of the Bauru Group in the State of São Paulo 1 [Port]; SBG São Paulo Chapter/ABAS: São Paulo, Brazil, 1981; pp. 37-57.

30. Maldaner, C.H. Aquifer Recharge in an Urban Area: Urânia (SP) Case Study [Port.]. Master's Thesis, University of de São Paulo, São Paulo, Brazil, 2010.

31. Instituto Geográfico e Geológico do Estado de São Paulo. Topographic Map (Scale 1:50.000) [Port.]. Folha Santa Albertina SF-22-D-I-2; IGG: São Paulo, Brazil, 1966.

32. Instituto Geográfico e Geológico do Estado de São Paulo. Topographic Map (Scale 1:50.000) [Port.]. Folha Jales SF-22-D-I-4; IGG: São Paulo, Brazil, 1966.

33. Almodovar, M.L.N. The Natural Origin of Chromium Pollution in the Adamantina Aquifer, Municipality of Urânia (SP), São Paulo [Port.]. Ph.D. Thesis, University of de São Paulo, São Paulo, Brazil, 2000.

34. Bertolo, R.; Hirata, R.; Sracek, O. Geochemistry and geochemical modeling of unsaturated zone in a tropical region in Urâia, São Paulo state, Brazil. J. Hydrol. 2006, 329, 49-62. [CrossRef]

35. Gutierrez, A.S. Hydrogeochemical Model of the Adamantina Aquifer in Urânia (SP). Master's Thesis, University of de São Paulo, São Paulo, Brazil, 2003. [CrossRef]

36. Paula e Silva, F.D. Surficial geology and hydrostratigraphy of The Bauru Group in The State of São Paulo [Port.]. Ph.D. Thesis, State University of São Paulo, São Paulo, Brazil, 2003; p. 154.

37. Palmér, R.M.I. A Numerical Model as a Tool to Understand Groundwater Circulation in Urânia (SP, Brazil). Master's Thesis, Luleå/Sweden Technologic University, Luleå, Sweden, 2002.

38. SABESP-Basic Sanitation Company of the State of São Paulo. Final Report of Deep Tubular Well, Urânia, Well 8. 1991, 8. Available online: http://site.sabesp.com.br/site/interna/Municipio.aspx?secaoId=18\&id=133 (accessed on 24 September 2020).

39. SABESP — Basic Sanitation Company of the State of São Paulo. Final Report of Deep Tubular Well, Aspásia (Urânia), Well 6. 1982, 8. Available online: http://site.sabesp.com.br/site/interna/Municipio.aspx?secaoId= $18 \& \mathrm{id}=440$ (accessed on 24 September 2020).

40. International Atomic Energy Agency. A new device for monthly rainfall sampling for GNIP. Water Environ. News 2002, 16, 5 .

41. CETESB - Environmental Company of the State of São Paulo. Nacional Sampling and Preservation Guide: Water, Sediments, Aquatic Communities and Liquid Effluents/Environmental Company of The State of São Paulo, organization: Carlos Jesus Bradã [et al.]; CETESB: São Paulo, Brazil; Agência Nacional de Águas (ANA) [Port]: Brasília, Brazil, 2011.

42. United States Environmental Protection Agency (USEPA). Drinking Water Regulations and Health Advisories 1985 URL. Available online: http://www.epa.gov (accessed on 24 September 2020).

43. American Public Health Association. Standard Methods for the Examination of Water and Wastewater, 19th ed.; American Public Health Association: Washington, DC, USA, 1995.

44. Brandão, C.J.; Botelho, M.J.C.; Sato, M.I.Z. National Guide for the Sampling and Preservation of Water, Sediment, Aquatic Communities and Liquid Effluents [Port.]; CETESB: São Paulo, Brazil; Agência Nacional de Águas (ANA) [Port]: Brasília, Brazil, 2011; p. 325. 
45. Neuman, S. Theory of flow in unconfined aquifers considering delayed response of the water table. Water Resour. Res. 1972, 8, 1031-1045. [CrossRef]

46. McDonald, M.G.; Harbaugh, A.W. A modular three-dimensional finite-difference groundwater flow model. Tech. Water Resour. Investig. 06-A1 1988, 576. [CrossRef]

47. Zheng, C. MT3DMS v. 5.2. Supplemental User's Guide. Tech. Rep. 2006, 41. Available online: https: //hydro.geo.ua.edu/mt3d/mt3dms_v5_supplemental.pdf (accessed on 24 September 2020).

48. Guiguer, N.; Franz, T. Visual MODFLOW. User's Manual; Waterloo Hydrogeologic: Waterloo, ON, Canada, 1996; p. 231.

49. Rozanski, K.; Araguás-Araguás, L.; Gonfiantini, R. Isotopic patterns in modern global precipitation. Climate change in continental isotopic records. GMS 1993, 78, 1-36. [CrossRef]

50. Bourotte, C.; Bertolo, R.; Almodovar, M.; Hirata, R. Natural occurrence of hexavalent chromium in a sedimentary aquifer in the State of São Paulo, Brazil. An. Acad. Bras. Ciências 2009, 81, 227-242. [CrossRef]

51. Bertolo, A.B.; Marcolan, L.N.O.; Bourotte, C.L.M. Water-Rock Interaction and the Hydrogeochemistry of Chromium in Groundwater from Multilevels Monitoring Wells in Urania, SP, Brazil. In Bibliographic Information; Instituto de Geociências da USP: São Paulo, Brazil, 2013; pp. 47-62. Available online: www.igc. usp.br/geologiausp (accessed on 18 September 2020).

(C) 2020 by the authors. Licensee MDPI, Basel, Switzerland. This article is an open access article distributed under the terms and conditions of the Creative Commons Attribution (CC BY) license (http://creativecommons.org/licenses/by/4.0/). 